\title{
The Endocannabinoid System as a Potential Mechanism through which Exercise Influences Episodic Memory Function
}

\author{
Paul D. Loprinzi ${ }^{1, *(1)}$, Liye Zou ${ }^{2}$ and Hong $\mathrm{Li}^{3,4,5, *}$ \\ 1 Exercise \& Memory Laboratory, Department of Health, Exercise Science and Recreation Management, \\ The University of Mississippi, Oxford, MS 38677, USA \\ 2 Lifestyle (Mind-Body Movement) Research Center, College of Psychology and Sociology, Shenzhen \\ University, Shenzhen 518060, China; liyezou123@gmail.com \\ 3 Shenzhen Key Laboratory of Affective and Social Cognitive Science, College of Psychology and Sociology, \\ Shenzhen University, Shenzhen 518060, China \\ 4 Research Centre of Brain Function and Psychological Science, Shenzhen University, Shenzhen 518060, China \\ 5 Shenzhen Institute of Neuroscience, Shenzhen University, Shenzhen 518060, China \\ * Correspondence: pdloprin@olemiss.edu (P.D.L.); lihongszu@szu.edu.cn (H.L.); \\ Tel.: +1-662-915-5561 (P.D.L.); +86-139-0297-3932 (H.L.)
}

Received: 4 May 2019; Accepted: 14 May 2019; Published: 16 May 2019

\begin{abstract}
Emerging research demonstrates that exercise, including both acute and chronic exercise, may influence episodic memory function. To date, mechanistic explanations of this effect are often attributed to alterations in long-term potentiation, neurotrophic production, angiogenesis, and neurogenesis. Herein, we discuss a complementary mechanistic model, suggesting that the endocannabinoid system may, in part, influence the effects of exercise on memory function. We discuss the role of the endocannabinoid system on memory function as well as the effects of exercise on endocannabinoid alterations. This is an exciting line of inquiry that should help delineate new insights into the mechanistic role of exercise on memory function.
\end{abstract}

Keywords: BDNF; CB1; CB2; episodic memory; exercise

\section{Introduction}

The purpose of the present review, written in a brief format, is to discuss a new potential mechanistic paradigm (endocannabinoid system) to elucidate the effects of exercise on episodic memory. This review is structured by first discussing the effects of exercise on memory; then briefly discussing the endocannabinoid system; then indicating the role of the endocannabinoid system on memory function; then how exercise may alter the function of the endocannabinoid system; and then lastly, introducing a hypothetical model indicating the potential moderational role of the endocannabinoid system on the exercise-memory interaction. This review is not meant to be an exhaustive review of the literature. Rather, the goal is to discuss a new mechanistic model and then succinctly provide support for the pathways within our model (Figure 1). Ultimately, the goal of this paper is to discuss a new mechanistic insight to help spawn the development of additional work in this important area of research. 


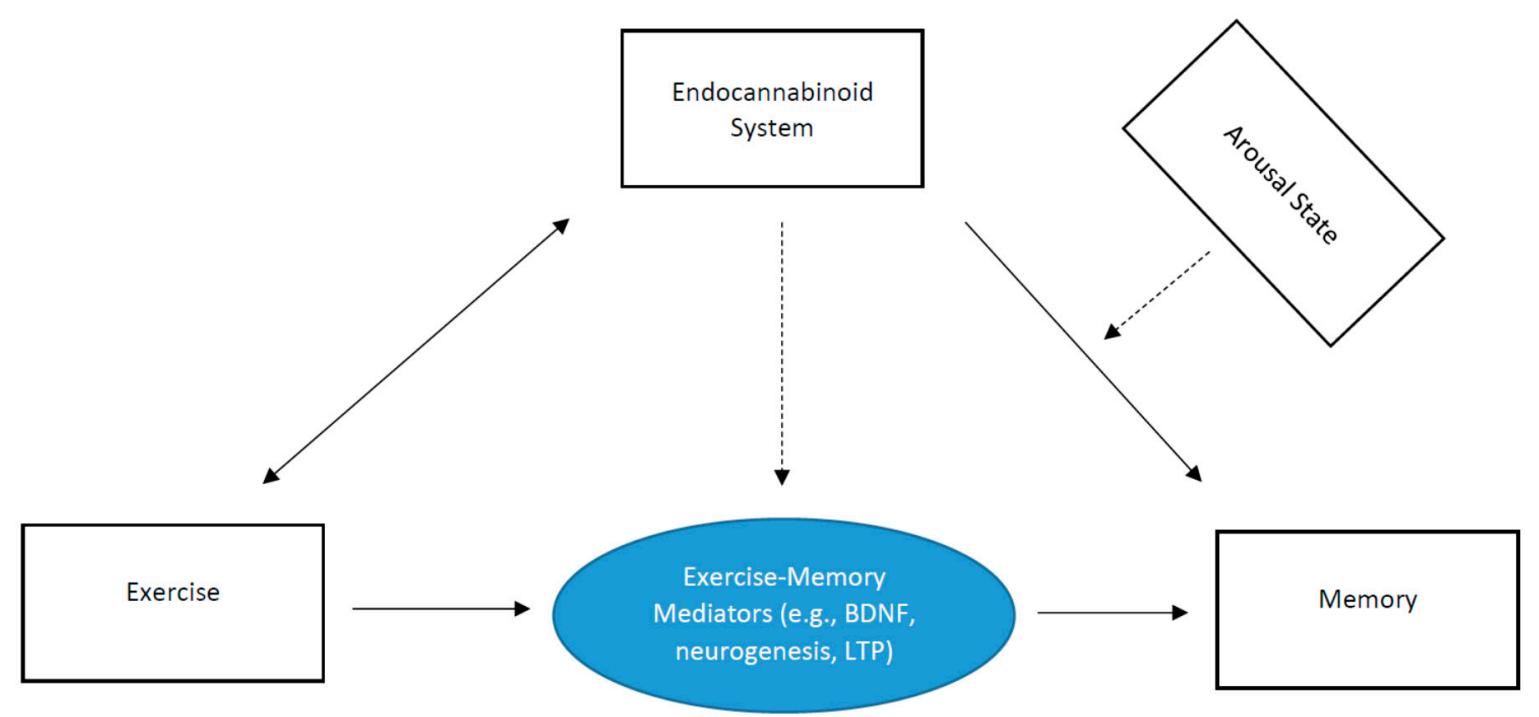

Figure 1. Schematic depicting the role of the endocannabinoid system on the exercise-memory interaction. The dashed lines indicate a moderation effect.

\section{Effects of Exercise on Memory}

Emerging research from our laboratory demonstrates that exercise, including both acute and chronic exercise, may be effective behaviors in enhancing memory function [1-9]. Various mediators of this exercise-memory interaction have been proposed [10-12]. From a chronic exercise perspective, potential mechanisms may occur at multiple levels, including molecular, cellular, and structural levels. At the molecular level, and as we have thoroughly detailed elsewhere [13-16], chronic exercise may increase levels of brain-derived neurotrophic factor (BDNF) [15,16], vascular endothelial growth factor (VEGF), insulin-like growth factor-1 (IGF-1) [14], and astrocytes [13]. These molecular alterations may induce cellular changes, including gliogenesis, neurogenesis, synaptogenesis, and angiogenesis. These cellular changes, in turn, may alter structural and functional adaptations, including increased white matter, gray matter, receptor activity, neural activity, and cerebral blood flow. Collectively, these molecular, cellular and structural/functional adaptations may improve behavioral performance in memory function.

From an acute exercise perspective, which we have discussed in detail elsewhere $[10,11,15,17]$, various exercise-induced alterations may help facilitate long-term potentiation, a cellular correlate of episodic memory [18]. Acute exercise, via, for example, muscle spindle activation, may increase neuronal excitability in key memory-related brain structures (e.g., hippocampus). This increased neuronal excitability may increase central levels of BDNF, which may help upregulate the expression and function of NMDA receptors. Downstream of this BDNF/TrkB signaling pathway, activation of the PI3K/AKT pathway may contribute to the maintenance of long-term potentiation via NMDA activity [19].

The present paper builds on our previous discussions of potential mechanisms through which exercise influences memory. That is, here we discuss a unique role of the endocannabinoid system in influencing the effects of exercise on memory function.

\section{The Endocannabinoid System}

Detailed information on the endocannabinoid system can be found elsewhere [20,21]. The cannabinoid system contains two notable subtypes of $G$ protein-coupled receptors, namely CB1 and CB2. The role of endocannabinoids on cognitive processes has mainly focused on CB1 receptors, which are widely distributed throughout the brain and body. CB1 receptors are distributed in the CNS (brainstem, cortex, nucleus, accumbens, hypothalamus, cerebellum, hippocampus, amygdala, spinal cord) and periphery (immune system, liver, bone marrow, pancreas, lungs, vascular system, 
muscles, GI tract, and reproductive organs) [22]. CB2 receptors are also distributed in the CNS (brainstem, glial cells) and periphery (immune system, liver, bone marrow, pancreas, spleen, bones, skin) [22].

\section{The Endocannabinoid System and Memory Function}

Previous reviews have detailed the role of the endocannabinoid system on memory function [22-24]. The influence of cannabinoids in memory function can be traced back to early work showing that marijuana intoxication (delta-9-tetrahydrocannabinol, THC) disrupts short-term memory function [25]. Such effects of THC on memory impairment appear to occur in a dose-dependent manner [26,27], with this disruption occurring primarily in the dentate gyrus, where high densities of cannabinoid receptors exist [28], and exist mainly in GABA-ergic inhibitory neurons. Further, memory impairment effects from marijuana may occur, in part, from its detrimental effects on information processing and reduced blood flow to the temporal lobe [24].

Acute systemic administration of CB1 agonists has been shown to impair acquisition of memory across multiple memory tasks, including the Morris water maze task [29]. Similar results have also been observed with intra-cranial administration of CB1 agonists [30]. Conversely, administration of antagonists of CB1 receptors has been shown to facilitate memory consolidation [31]. Blockage of CB1 receptors increases the release of acetylcholine (ACh) [32], a neurotransmitter essential for memory and learning.

Cannabinoid receptor activation may impair memory through various pathways. For example, activation of CB1 receptors is connected with inhibition of adenyl cyclase as well as calcium channels and leads to the activation of potassium channels [22]. As a result, this leads to short-term depression of neurotransmitter release. More specifically, CB1 receptor activation may inhibit cAMP accumulation within neurons, inhibit glutamate release, and inhibit voltage-activated calcium currents [33-35], of which may reduce the excitability of hippocampal neurons, and in turn, reduce neural transmission [32]. Further, cannabinoid agonists may interfere with long-term potentiation [36]. Notably, however, previous work has shown that pre-incubation of adult rat hippocampal slices with THC can either inhibit or potentiate long-term potentiation, depending on the concentration used [37]. Possible explanations for contrasting results for THC on memory is that cannabinoid receptors are expressed at both glutamatergic and GABA-ergic synapses, which often exert opposite effects on memory [38]. For example, CB1 activation from low doses impacts glutamatergic transmission, whereas higher doses affect GABA-ergic transmission [39]. Relatedly, a chronic low dose of THC has been shown to reverse age-related decline in cognitive performance, via enhanced expression of synaptic markers and increased hippocampal spine density [40]. Further, cannabinoid-induced depression of synaptic transmission is switched to stimulation when dopaminergic tone is increased [41]. Although less investigated than CB1 receptors, recent work suggests an important role of CB2 receptors in memory function [42]. Chronic activation of CB2 receptors in the hippocampus for 7-10 days has been shown to increase excitatory synaptic transmission [43]. Similarly, other related work demonstrates that $\mathrm{CB} 2$ receptors play an important role in the modulation of memory consolidation for aversive experiences [44]. Further, CB2 receptor agonists reduce neurodegeneration, neuroinflammation, and attenuates spatial memory impairment in an Alzheimer's disease model [45]. Relatedly, CB2 knockout has been shown to impair contextual long-term memory [46]. In addition to direct activation of CB2 receptors, other work also demonstrates the important role of key enzymes (e.g., fatty acid amide hydrolase, FAAH) that are responsible for the metabolism of key endocannabinoids (e.g., anandamide) [47]. For example, recent work has shown that FAAH inhibition modulates hippocampal microglial recruitment and activation that is associated with improved hippocampal-dependent memory [48]. Relatedly, FAAH inhibitor (URB597) infusion, which selectively increased anandamide levels at active synapses, enhanced emotional memory via consolidation-based processes [49]. Treatment with URB597 has also been shown to restore age-related decreases in long-term potentiation in the dentate gyrus [50]. 
The conflicting findings of the endocannabinoid system on memory function may also be context-dependent. As thoroughly detailed elsewhere [44], the endocannabinoid system may shape how environmental stimuli influence emotional responses. In a low arousal state, endocannabinoid activation was not associated with memory in rats, which was in contrast to their findings in a high arousal state, showing that short-term memory was enhanced when endocannabinoid activation occurred during the early memory consolidation stage [45]. Thus, environmental or behavioral events that influence different levels of stress and arousal may shape the responses to the memory effects of the cannabinoid system. As detailed elsewhere [44], emotionally arousing experiences, such as stress and physical exercise, increase stress hormones (e.g., cortisol and epinephrine), which bind to metabotropic receptors within the basolateral complex of the amygdala, activating the cAMP/PKA pathway to induce endocannabinoid synthesis. Endocannabinoids are then released, bind to GABAergic terminals, inhibits GABA release, and in turn, increase noradrenergic activation of postsynaptic $\beta$-adrenoceptors, ultimately facilitating memory consolidation of emotional/arousing events. These effects may, in part, help explain the potential beneficial effects of exercise on memory function. This may be particularly true for studies evaluating the effects of exercise on emotional memory. As we demonstrated recently [51], when exercise occurs during the memory consolidation stage, emotional memory is enhanced, whereas when it occurs prior to memory encoding, it remains unaffected [52].

\section{Exercise and the Endocannabinoid System}

Several studies have demonstrated that endocannabinoid levels may be altered with exercise [53,54], with their effects acting both centrally and peripherally [54]. Exercise has been shown to enhance CB1 receptor sensitivity [55]. Sparling et al. [56] demonstrated that higher levels of physical activity were associated with greater anandamide (an endogenous agonist of the cannabinoid CB1 and CB2 receptors) levels. Among rodents, Hill et al. [57] showed that 8 days of exercise increased anandamide levels. Further, Raichlen et al. [58] showed an intensity-dependent effect of exercise on anandamide levels, with moderate-intensity exercise enhancing anandamide levels. Fuss et al. [59] showed that wheel running increases endocannabinoid levels and ablation of CB1 receptors on GABAergic neurons inhibits running-induced anxiolysis. Notably, however, a bi-directional relationship may also exist, as research demonstrates that stimulation of $\mathrm{CB} 1$ receptors is a prerequisite for voluntary running in mice [60-62]. For example, CB1 activation on VTA (ventral tegmental area) GABAergic neurons may trigger disinhibition of VTA dopamine [60], implicated in reward-directed processes.

\section{Hypothetical Model}

Emerging work has started to evaluate the potential role of the cannabinoid system on subserving the exercise-memory relationship. Research demonstrates that exercise-induced hippocampal cell proliferation and neurogenesis depends on CB1 receptor signaling [57,63,64]. Notably, CB1 receptors have widespread expression over the entire dentate gyrus and voluntary wheel running has been shown to increase CB1 receptor mRNA in the hippocampus [63]. CB1 receptors specifically affect the stages of adult neurogenesis and the survival and maturation of new neurons [63].

Relatedly, research demonstrates that treadmill running improves spatial memory in mice, which is prevented by simultaneous treatment of a CB1 receptor antagonist [65]. Such exercise-related effects may be attributed to exercise-induced increases in CB1 receptor activation and BDNF expression in the hippocampus [65]. Thus, exercise-induced enhancement of memory function may, in part, be due to a number of endocannabinoid signaling mechanisms related to long-term potentiation, production of neurotrophic factors, and cellular neurogenesis. This is schematically illustrated in Figure 1. That is, there exists a bi-directional relationship between exercise and endocannabinoid levels. The endocannabinoid system may play an important role in episodic memory function, and as demonstrated previously, this may be moderated by arousal state. Further, key exercise-induced mechanisms (e.g., neurogenesis) that influence episodic memory function may be moderated by the endocannabinoid system. Key insight and support of this model have been demonstrated recently. 
Bosch et al. [66] evaluated the effects of acute exercise intensity on memory function, with considerations of AEA (anandamide) and BDNF in mediating this relationship. Their results demonstrated consistent evidence of moderate-intensity acute exercise enhancing associative memory. They also demonstrated that increased AEA after moderate-intensity exercise correlated with neural activation of the right hippocampus [66].

\section{Model Evaluation}

Future work is needed to evaluate this model and, when appropriate, make necessary revisions. Such work should employ both acute and chronic exercise paradigms. From an acute exercise perspective, future within-subject experimental designs should employ multiple exercise intensities (e.g., control, moderate, and vigorous), and when doing so, carefully consider the temporal effects of acute exercise on memory function [4]. That is, consider integrating the acute bout of exercise prior to memory encoding and across different phases of memory consolidation. In human models, blood samples to assess endocannabinoid levels should be measured at multiple time points (e.g., before and after exercise; prior to memory encoding and retrieval, and during memory consolidation). Similarly, key mediators (e.g., BDNF, LTP) through which the endocannabinoid system may influence the effects of acute exercise on memory will need to be assessed at these time points. In human work, novel methodologies to assess LTP will need to be considered. For example, evaluating LTP-like responses, such as visually-evoked event-related potentials, is worth considering [67]. Further, the memory assessments should be carefully considered, and, for example, include hippocampal-dependent memory tasks and emotional memory tasks (given the abundance of CB1 receptors in the limbic system).

Among human models, chronic exercise training studies should carefully design the study to ensure that any potential effects are due to the chronic training stimulus, as opposed to a potential acute exercise response. Rarely do chronic training studies indicate whether participants avoided exercise shortly before the post-training memory assessment, and as such, it is challenging to determine whether post-training outcomes are from chronic adaptations from exercise, or rather, are an artifact of an acute exercise response. These chronic training studies should evaluate other potential mediators through which the endocannabinoid system may influence, such as neurogenesis, which can be measured from magnetic resonance imaging [68]. Lastly, animal studies should continue to design experimental studies that evaluate whether exercise activates the endocannabinoid system, whether this activation is associated with memory function, and whether blocking the endocannabinoid system prevents a direct effect of exercise on memory function.

\section{Summary}

In conclusion, this brief narrative review highlights the potential role of the cannabinoid system on the exercise-memory relationship. Future research is needed to fully test out this potential mechanistic paradigm. Such work should also delineate whether the site of CB1 activation (e.g., GABA-ergic, glutamatergic) moderates this relationship. This is an exciting line of inquiry that should help delineate new insights into the mechanistic role of exercise on memory function.

Author Contributions: P.D.L. conceptualized the model and drafted the manuscript. L.Z. and H.L. provided insights and feedback in revising the manuscript.

Funding: This research project is supported by both Guangdong-Government Funding for Scientific Research (2016KZDXM009) and Shenzhen-Government Research Grants Programme in Basic Sciences (JCYJ20150729104249783).

Conflicts of Interest: The authors declare no conflict of interest. 


\section{References}

1. Loprinzi, P.D.; Frith, E.; Edwards, M.K.; Sng, E.; Ashpole, N. The Effects of Exercise on Memory Function Among Young to Middle-Aged Adults: Systematic Review and Recommendations for Future Research. Am. J. Health Promot. 2018, 32, 691-704. [CrossRef]

2. Iv, J.T.H.; Frith, E.; Sng, E.; Loprinzi, P.D. Experimental Effects of Acute Exercise on Episodic Memory Function: Considerations for the Timing of Exercise. Psychol. Rep. 2018, 33294118786688.

3. Johnson, L.; Loprinzi, P.D. The effects of acute exercise on episodic memory function among young University students: Moderation considerations by biological sex. Health Promot. Perspect. 2019.

4. Loprinzi, P.D.; Blough, J.; Crawford, L.; Ryu, S.; Zou, L.; Li, H. The Temporal Effects of Acute Exercise on Episodic Memory Function: Systematic Review with Meta-Analysis. Brain Sci. 2019, 9, 87. [CrossRef] [PubMed]

5. Loprinzi, P.D.; Frith, E.; Edwards, M.K. Resistance exercise and episodic memory function: a systematic review. Clin. Physiol. Funct. Imaging 2018, 38, 923-929. [CrossRef] [PubMed]

6. Ponce, P.; Loprinzi, P.D. A bi-directional model of exercise and episodic memory function. Med. Hypotheses 2018, 117, 3-6. [CrossRef]

7. Siddiqui, A.; Loprinzi, P.D. Experimental Investigation of the Time Course Effects of Acute Exercise on False Episodic Memory. J. Clin. Med. 2018, 7, 157. [CrossRef] [PubMed]

8. Sng, E.; Frith, E.; Loprinzi, P.D. Experimental effects of acute exercise on episodic memory acquisition: Decomposition of multi-trial gains and losses. Physiol. Behav. 2018, 186, 82-84. [CrossRef]

9. Loprinzi, P.D.; Scott, T.M.; Ikuta, T.; Addoh, O.; Tucker, K.L. Association of physical activity on changes in cognitive function: Boston Puerto Rican Health Study. Physician Sportsmed. 2018, 47, 227-231. [CrossRef]

10. Loprinzi, P.D.; Edwards, M.K.; Frith, E. Potential avenues for exercise to activate episodic memory-related pathways: a narrative review. Eur. J. Neurosci. 2017, 46, 2067-2077. [CrossRef]

11. Frith, E.; Loprinzi, P.D. Physical activity and individual cognitive funcion parameters: unique exercise-induced mechansims. J. Cognit. Behav. Psychother. Res. 2018, 7, 92-106. [CrossRef]

12. El-Sayes, J.; Harasym, D.; Turco, C.V.; Locke, M.B.; Nelson, A.J. Exercise-Induced Neuroplasticity: A Mechanistic Model and Prospects for Promoting Plasticity. Neuroscientist 2019, 25, 65-85. [CrossRef] [PubMed]

13. Loprinzi, P. The role of astrocytes on the effects of exercise on episodic memory function. Physiol. Int. 2019, 106, 21-28. [CrossRef]

14. Loprinzi, P.D. IGF-1 in exercise-induced enhancement of episodic memory. Acta Physiol. 2018, 226 , e13154. [CrossRef] [PubMed]

15. Loprinzi, P.D.; Frith, E. A brief primer on the mediational role of BDNF in the exercise-memory link. Clin. Physiol. Funct. Imaging 2019, 39, 9-14. [CrossRef]

16. Loprinzi, P.D. Does brain-derived neurotrophic factor mediate the effects of exercise on memory? Physician Sportsmed. 2019, 1-11. [CrossRef] [PubMed]

17. Loprinzi, P.; Ponce, P.; Frith, E. Hypothesized mechanisms through which acute exercise influences episodic memory. Physiol. Int. 2018, 105, 285-297. [CrossRef]

18. Poo, M.-M.; Pignatelli, M.; Ryan, T.J.; Tonegawa, S.; Bonhoeffer, T.; Martin, K.C.; Rudenko, A.; Tsai, L.-H.; Tsien, R.W.; Fishell, G.; et al. What is memory? The present state of the engram. BMC Boil. 2016, 14, 1133. [CrossRef]

19. Nakai, T.; Nagai, T.; Tanaka, M.; Itoh, N.; Asai, N.; Enomoto, A.; Asai, M.; Yamada, S.; Saifullah, A.B.; Sokabe, M.; et al. Girdin Phosphorylation Is Crucial for Synaptic Plasticity and Memory: A Potential Role in the Interaction of BDNF/TrkB/Akt Signaling with NMDA Receptor. J. Neurosci. 2014, 34, 14995-15008. [CrossRef]

20. Zou, S.; Kumar, U. Cannabinoid Receptors and the Endocannabinoid System: Signaling and Function in the Central Nervous System. Int. J. Mol. Sci. 2018, 19, 833.

21. Mechoulam, R.; Parker, L.A. The Endocannabinoid System and the Brain. Annu. Psychol. 2013, 64, 21-47. [CrossRef] [PubMed]

22. Kruk-Slomka, M.; Dzik, A.; Budzynska, B.; Biala, G. Endocannabinoid System: The Direct and Indirect Involvement in the Memory and Learning Processes-a Short Review. Mol. Neurobiol. 2017, 54, 8332-8347. [CrossRef] [PubMed] 
23. Hampson, R.E.; Deadwyler, S.A. Role of Cannabinoid Receptors in Memory Storage. Neurobiol. Dis. 1998, 5, 474-482. [CrossRef] [PubMed]

24. Riedel, G.; Davies, S.N. Cannabinoid Function in Learning, Memory and Plasticity. Cannabinoids 2005, 168, 445-477.

25. Miller, L.L.; Branconnier, R.J. Cannabis: Effects on memory and the cholinergic limbic system. Psychol. Bull. 1983, 93, 441-456. [CrossRef]

26. Campbell, K.A.; Foster, T.C.; Hampson, R.E.; Deadwyler, S.A. Effects of delta 9-tetrahydrocannabinol on sensory-evoked discharges of granule cells in the dentate gyrus of behaving rats. J. Pharmacol. Exp. Ther. 1986, 239, 941-945. [PubMed]

27. Campbell, K.A.; Foster, T.C.; Hampson, R.E.; Deadwyler, S.A. delta 9-Tetrahydrocannabinol differentially affects sensory-evoked potentials in the rat dentate gyrus. J. Pharmacol. Exp. Ther. 1986, 239, 936-940. [PubMed]

28. Deadwyler, S.A.; Hampson, R.E.; Childers, S.R. Functional significance of cannabinoid receptors in brain. In Cannabinoid Receptors; Pertwee, R.G., Ed.; Academic Press: London, UK, 1995; pp. 205-231.

29. Wise, L.E.; Long, K.A.; Abdullah, R.A.; Long, J.Z.; Cravatt, B.F.; Lichtman, A.H. Dual Fatty Acid Amide Hydrolase and Monoacylglycerol Lipase Blockade Produces THC-Like Morris Water Maze Deficits in Mice. ACS Chem. Neurosci. 2012, 3, 369-378. [CrossRef]

30. Abush, H.; Akirav, I. Cannabinoids modulate hippocampal memory and plasticity. Hippocampus 2010, 20, 1126-1138. [CrossRef]

31. Takahashi, R.N.; Pamplona, F.A.; Fernandes, M.S. The cannabinoid antagonist SR141716A facilitates memory acquisition and consolidation in the mouse elevated T-maze. Neurosci. Lett. 2005, 380, 270-275. [CrossRef]

32. Kruk-Slomka, M.; Biala, G. CB1 receptors in the formation of the different phases of memory-related processes in the inhibitory avoidance test in mice. Behav. Brain 2016, 301, 84-95. [CrossRef] [PubMed]

33. Howlett, A.C.; Johnson, M.R.; Melvin, L.S.; Milne, G.M. Nonclassical cannabinoid analgetics inhibit adenylate cyclase: development of a cannabinoid receptor model. Mol. Pharmacol. 1988, 33, 297-302. [PubMed]

34. Twitchell, W.; Brown, S.; Mackie, K. Cannabinoids Inhibit N- and P/Q-Type Calcium Channels in Cultured Rat Hippocampal Neurons. J. Neurophysiol. 1997, 78, 43-50. [CrossRef] [PubMed]

35. Shen, M.; Piser, T.M.; Seybold, V.S.; Thayer, S.A. Cannabinoid Receptor Agonists Inhibit Glutamatergic Synaptic Transmission in Rat Hippocampal Cultures. J. Neurosci. 1996, 16, 4322-4334. [CrossRef]

36. Stella, N.; Schweitzer, P.; Piomelli, D. A second endogenous cannabinoid that modulates long-term potentiation. Nat. Cell Boil. 1997, 388, 773-778. [CrossRef] [PubMed]

37. Nowicky, A.V.; Teyler, T.J.; Vardaris, R.M. The modulation of long-term potentiation by delta-9-tetrahydrocannabinol in the rat hippocampus, in vitro. Brain Res. Bull. 1987, 19, 663-672. [CrossRef]

38. Ruehle, S.; Rey, A.A.; Remmers, F.; Lutz, B. The endocannabinoid system in anxiety, fear memory and habituation. J. Psychopharmacol 2012, 26, 23-39. [CrossRef]

39. Busquets-Garcia, A.; Bains, J.; Marsicano, G. CB1 Receptor Signaling in the Brain: Extracting Specificity from Ubiquity. Neuropsychopharmacolo. 2018, 43, 4-20. [CrossRef]

40. Bilkei-Gorzo, A.; Albayram, O.; Draffehn, A.; Michel, K.; Piyanova, A.; Oppenheimer, H.; Dvir-Ginzberg, M.; Rácz, I.; Ulas, T.; Imbeault, S.; et al. A chronic low dose of $\Delta 9$-tetrahydrocannabinol (THC) restores cognitive function in old mice. Nat. Med. 2017, 23, 782-787. [CrossRef]

41. Caballero-Florán, R.N.; Conde-Rojas, I.; Chávez, A.O.; Cortes-Calleja, H.; Lopez-Santiago, L.F.; Isom, L.L.; Aceves, J.; Erlij, D.; Florán, B. Cannabinoid-induced depression of synaptic transmission is switched to stimulation when dopaminergic tone is increased in the globus pallidus of the rodent. Neuropharmacology 2016, 110, 407-418. [CrossRef] [PubMed]

42. Ratano, P.; Palmery, M.; Trezza, V.; Campolongo, P. Cannabinoid Modulation of Memory Consolidation in Rats: Beyond the Role of Cannabinoid Receptor Subtype 1. Front. Pharmacol. 2017, 8, 45. [CrossRef]

43. Kim, J.; Li, Y. Chronic activation of CB2 cannabinoid receptors in the hippocampus increases excitatory synaptic transmission. J. Physiol. 2015, 593, 871-886. [CrossRef]

44. Ratano, P.; Petrella, C.; Forti, F.; Passeri, P.P.; Morena, M.; Palmery, M.; Trezza, V.; Severini, C.; Campolongo, P. Pharmacological inhibition of 2-arachidonoilglycerol hydrolysis enhances memory consolidation in rats through CB2 receptor activation and mTOR signaling modulation. Neuropharmacology 2018, 138, 210-218. [CrossRef] 
45. Çakır, M.; Tekin, S.; Doğanyiğit, Z.; Erden, Y.; Soytürk, M.; Çiğremiş, Y.; Sandal, S. Cannabinoid type 2 receptor agonist JWH-133, attenuates Okadaic acid induced spatial memory impairment and neurodegeneration in rats. Life Sci. 2019, 217, 25-33. [CrossRef]

46. Li, Y.; Kim, J. CB2 Cannabinoid Receptor Knockout in Mice Impairs Contextual Long-Term Memory and Enhances Spatial Working Memory. Neural Plast. 2016, 2016, 9817089. [CrossRef]

47. Ahn, K.; Johnson, D.S.; Cravatt, B.F. Fatty acid amide hydrolase as a potential therapeutic target for the treatment of pain and CNS disorders. Expert Opin. Drug Discov. 2009, 4, 763-784. [CrossRef]

48. Rivera, P.; Fernández-Arjona, M.D.M.; Silva-Peña, D.; Blanco, E.; Vargas, A.; López-Ávalos, M.D.; Grondona, J.M.; Serrano, A.; Pavón, F.J.; De Fonseca, F.R.; et al. Pharmacological blockade of fatty acid amide hydrolase (FAAH) by URB597 improves memory and changes the phenotype of hippocampal microglia despite ethanol exposure. Biochem. Pharmacol. 2018, 157, 244-257. [CrossRef]

49. Morena, M.; Roozendaal, B.; Trezza, V.; Ratano, P.; Peloso, A.; Hauer, D.; Atsak, P.; Trabace, L.; Cuomo, V.; McGaugh, J.L.; et al. Endogenous cannabinoid release within prefrontal-limbic pathways affects memory consolidation of emotional training. Proc. Acad. Sci. 2014, 111, 18333-18338. [CrossRef] [PubMed]

50. Murphy, N.; Cowley, T.R.; Blau, C.W.; Dempsey, C.N.; Noonan, J.; Gowran, A.; Tanveer, R.; Olango, W.M.; Finn, D.P.; Campbell, V.; et al. The fatty acid amide hydrolase inhibitor URB597 exerts anti-inflammatory effects in hippocampus of aged rats and restores an age-related deficit in long-term potentiation. J. Neuroinflammation 2012, 9, 79. [CrossRef] [PubMed]

51. Loprinzi, P.D.; Frith, E.; Edwards, M.K. Exercise and Emotional Memory: a Systematic Review. J. Cogn. Enhanc. 2018, 3, 94-103. [CrossRef]

52. Wade, B.; Loprinzi, P.D. The Experimental Effects of Acute Exercise on Long-Term Emotional Memory. J. Clin. Med. 2018, 7, 486. [CrossRef] [PubMed]

53. Thompson, Z.; Argueta, D.; Garland, T., Jr.; DiPatrizio, N. Circulating levels of endocannabinoids respond acutely to voluntary exercise, are altered in mice selectively bred for high voluntary wheel running, and differ between the sexes. Physiol. Behav. 2017, 170, 141-150. [CrossRef] [PubMed]

54. Dietrich, A.; McDaniel, W.F. Endocannabinoids and exercise. Br. J. Sports Med. 2004, 38, 536-541. [CrossRef] [PubMed]

55. De Chiara, V.; Errico, F.; Musella, A.; Rossi, S.; Mataluni, G.; Sacchetti, L.; Siracusano, A.; Castelli, M.; Cavasinni, F.; Bernardi, G. Voluntary exercise and sucrose consumption enhance cannabinoid CB1 receptor sensitivity in the striatum. Neuropsychopharmacology 2010, 35, 374-387. [CrossRef] [PubMed]

56. Sparling, P.B.; Giuffrida, A.; Piomelli, D.; Rosskopf, L.; Dietrich, A. Exercise activates the endocannabinoid system. NeuroReport 2003, 14, 2209-2211. [CrossRef]

57. Hill, M.N.; McLaughlin, R.J.; Bingham, B.; Shrestha, L.; Lee, T.T.Y.; Gray, J.M.; Hillard, C.J.; Gorzalka, B.B.; Viau, V. Endogenous cannabinoid signaling is essential for stress adaptation. Proc. Acad. Sci. 2010, 107, 9406-9411. [CrossRef]

58. Raichlen, D.A.; Foster, A.D.; Seillier, A.; Giuffrida, A.; Gerdeman, G.L. Exercise-induced endocannabinoid signaling is modulated by intensity. Eur. J. Appl. Physiol. 2013, 113, 869-875. [CrossRef]

59. Fuss, J.; Steinle, J.; Bindila, L.; Auer, M.K.; Kirchherr, H.; Lutz, B.; Gass, P. A runner's high depends on cannabinoid receptors in mice. Proc. Acad. Sci. 2015, 112, 13105-13108. [CrossRef] [PubMed]

60. Dubreucq, S.; Durand, A.; Matias, I.; Benard, G.; Richard, E.; Soria-Gómez, E.; Glangetas, C.; Groc, L.; Wadleigh, A.; Massa, F.; et al. Ventral Tegmental Area Cannabinoid Type-1 Receptors Control Voluntary Exercise Performance. Boil. Psychiatry 2013, 73, 895-903. [CrossRef]

61. Chaouloff, F.; Dubreucq, S.; Bellocchio, L.; Marsicano, G. Endocannabinoids and Motor Behavior: CB1 Receptors Also Control Running Activity. Physiology 2011, 26, 76-77. [CrossRef] [PubMed]

62. Fuss, J.; Gass, P. Endocannabinoids and voluntary activity in mice: Runner's high and long-term consequences in emotional behaviors. Exp. Neurol. 2010, 224, 103-105. [CrossRef] [PubMed]

63. Wolf, S.A.; Bick-Sander, A.; Fabel, K.; Leal-Galicia, P.; Tauber, S.; Ramírez-Rodríguez, G.; Müller, A.; Melnik, A.; Waltinger, T.P.; Ullrich, O.; et al. Cannabinoid receptor CB1 mediates baseline and activity-induced survival of new neurons in adult hippocampal neurogenesis. Cell Commun. Signal. 2010, 8, 12. [CrossRef] [PubMed]

64. Hill, M.N.; Titterness, A.K.; Morrish, A.C.; Carrier, E.; Lee, T.; Gil-Mohapel, J.; Gorzalka, B.; Hillard, C.; Christie, B. Endogenous cannabinoid signaling is required for voluntary exercise-induced enhancement of progenitor cell proliferation in the hippocampus. Hippocampus 2010, 20, 513-523. [CrossRef] 
65. Ferreira-Vieira, T.H.; Bastos, C.P.; Pereira, G.S.; Moreira, F.A.; Massensini, A.R. A role for the endocannabinoid system in exercise-induced spatial memory enhancement in mice. Hippocampus 2014, 24, 79-88. [CrossRef] [PubMed]

66. Bosch, B.M.; Bringard, A.; Logrieco, M.G.; Lauer, E.; Imobersteg, N.; Ferretti, G.; Thomas, A.; Schwartz, S.; Igloi, K. Acute physical exercise of moderate intensity improves memory consolidation in humans via BDNF and endocannabinoid signaling. bioRxiv 2019. [CrossRef]

67. Smallwood, N.; Spriggs, M.J.; Thompson, C.S.; Wu, C.C.; Hamm, J.P.; Moreau, D.; Kirk, I.J. Influence of Physical Activity on Human Sensory Long-Term Potentiation. J. Int. Neuropsychol. Soc. 2015, 21, 831-840. [CrossRef]

68. Sierra, A.; Encinas, J.M.; Maletic-Savatic, M. Adult Human Neurogenesis: From Microscopy to Magnetic Resonance Imaging. Front. Neurosci. 2011, 5, 47. [CrossRef] [PubMed]

(C) 2019 by the authors. Licensee MDPI, Basel, Switzerland. This article is an open access article distributed under the terms and conditions of the Creative Commons Attribution (CC BY) license (http://creativecommons.org/licenses/by/4.0/). 